\title{
The Opportunity Cost of Reduced Timber Harvests Resulting from Coal Mine Development: A Case Study
}

\author{
by
}

\author{
Glen W. Armstrong ${ }^{1}$, William E. Phillips ${ }^{1}$ and James A. Beck, Jr. ${ }^{2}$
}

\begin{abstract}
This paper presents a methodology for determining the opportunity cost of a temporary removal of forested land from timber production. The value of forested land in a jurisdiction requiring sustained timber yield is the net value of the contribution of that land to the annual allowable cut. This methodology is used in a case study in west central Alberta to determine the opportunity cost of the removal of land from timber production to allow for coal extraction.
\end{abstract}

\section{Résumé}

Cet article présente une méthodologie pour déterminer le coût de revient du retrait temporaire d'un terrain forestier des terres forestières productives. La valeur du terrain forestier assujetti à un rendement soutenu de matière ligneuse est la valeur nette de la contribution de ce terrain à la coupe annuelle admissible. Cette méthodologie est utilisée dans un cas-type du centre ouest de l'Alberta afin de déterminer le coût de revient du retrait d'un terrain des terres forestières productives lors de l'extraction du charbon.

\section{Introduction}

Land resources can be used for different activities satisfying different demands. Many of these uses are mutually exclusive, leading to land use trade-offs. Timber harvesting may conflict with agricultural, industrial, residential, park, or mining uses of the land. Displacement of timber production results in foregone future net revenues from timber production (i.e. timber revenue less production costs). In the context of economic analysis, this foregone net revenue becomes an opportunity cost that must be charged against the displacing resource use.

During the 1970's in Alberta, energy and agricultural resource use demands rose drastically. This development gave impetus to the expansion of agricultural production and coal mining. Both of these resource use increases resulted in the displacement of timber producing areas in the province. Determination of the opportunity cost of displaced wood production from agriculture has been undertaken (Phillips et al. 1988). The methodology used in Phillips' study is slightly modified here and is applied to a coal extraction vs. timber harvest case study involving a coal mine in west central Alberta.

The technique used is conceptually straight forward. Given a sustained timber yield policy such as that in place in Alberta, the value of a tract of land and the timber on it for timber production is the value of its contribution to the sustained yield allowable annual cut (AAC) of the forest management unit (FMU) of interest. Potential harvest volume flows over time are estimated for the FMU assuming that the entire land base remains in timber production and assuming that a proposed land use change occurs. The difference between the two time flows of estimated harvest volume is

Department of Rural Economy, University of Alberta, Edmonton T6G $2 \mathrm{H} 1$
${ }^{2}$ Department of Forest Science, University of Alberta, Edmonton T6G $2 \mathrm{H} 1$ multiplied by an estimated timber value and discounted appropriately to determine the cost of lost timber production opportunities. Stated mathematically, the opportunity cost is

$$
\mathrm{OC}=\sum_{\mathrm{t}=1}^{\infty}\left[\frac{\mathrm{TV}\left(\mathrm{AAC}_{\mathrm{Nt}}-\mathrm{AAC} \mathrm{C}_{\mathrm{t}}\right)}{(1+i)^{\mathrm{t}}}\right]
$$

where $\mathrm{OC}$ is the cost of lost timber production opportunities,

$t$ is the time in years,

TV is the net value of standing timber $\left(\$ / \mathrm{m}^{3}\right)$,

$A A C_{N t}$ is the estimated $A A C$ for year $t$ assuming no land use change,

$A A C_{D t}$ is the estimated $A A C$ for year $t$ assuming the

land use change occurs, and

$i$ is the discount rate.

\section{Study Area}

Much of the information used for this study was graciously provided by St. Regis (Alberta) Ltd. (now Weldwood of Canada Limited [Hinton Division]) and the Obed Mountain Coal Company. The pulp company operates a bleached kraft pulp and stud mill complex in the town of Hinton in west central Alberta. Much of the wood fibre input to the complex is obtained from the company's forest management area (FMA) which is divided into several working circles for administrative purposes. Each working circle is managed on a sustained timber yield basis.

In the early 1980's, the Obed Mountain Coal Company began development of the Obed coal lease as an open pit thermal coal mine. This lease is located within the boundaries of the Athabasca Working Circle of the pulp company's FMA and occupies 3254 ha, of which 2791 ha is commercial forest land. The entire working circle comprises 119248 ha of commercial forest land. All of the mature timber located in the Obed Block was harvested before development of the coal lease so the forest cover on the area consists of young second growth forest. The Environmental and Socio- 
Economic Impact Assessment for the coal project (Anon. 1979) reported that the average height of the forest cover on the Obed Block was $2.3 \mathrm{~m}$. It will be some decades before any of this regenerated forest is ready for harvest.

The proposed timing for the development of the Obed block is detailed in the impact assessment. Different areas of the block are scheduled for development in each year of the expected life of the mine. For purposes of this study the mine area is divided into five areas. Area 1 represents the area scheduled for development in years -1 through 9 ; area 2 is the area scheduled for development in years 10 through 19 ; area 3 is the area scheduled for development in years 20 through 29; area 4 is the area scheduled for development in years 30 through 37 ; and area 5 represents the proposed plant site including roads and retention pond. Except for area 5 , each area represents approximately one decade of mining.

\section{Harvest Volume Estimation}

Alberta government policy guides the determination of an $A A C$ for a forest management unit (or working circle, using company terminology). The AAC should be set so that the volume harvested from the management unit over a selected conversion period is maximized subject to nondeclining harvest level costraints (Anon. 1985a). The linear programming based harvest scheduling model Timber RAM (Navon 1971) is commonly used in western Canada to estimate allowable cuts under this type of policy and was used in this study ${ }^{3}$.

Individual forest stands are aggregated into timber classes for analysis with Timber RAM. A timber class is simply a collection of stands similar enough to each other to be treated as one unit for analysis purposes. Stands were assigned to timber classes in the manner outlined below.

Stands outside of the coal lease were first divided into forest type groups (pine, white spruce, black spruce, fir, hardwood, and second growth). A Chapman-Richards yield curve was developed for each forest type group using regression analysis on data provided by the pulp company ${ }^{4}$. The type groups were further subdivided into age classes to create the timber classes used for the Timber RAM analysis. There were a total of 38 timber classes used in this analysis. Regenerated timber was assumed to follow growth curves similar to those developed for existing timber, but adjusted to account for regeneration lags. The coefficients of the yield curves are presented in Table 1.

Stands within the Obed coal lease block were separated from those outside of the coal lease. The stands within the Obed Block were divided into five groups representing the five mine areas mentioned previously. Each of these groups was further divided based on the age class of the forest cover. The yield curve used for the timber on the mine area is the curve developed for second growth timber.

Figure 1 shows the age class structure of the Athabasca working circle and Figure 2 shows the area by forest type of the working circle. These figures were derived from inventory data provided by the Alberta Forest Service. The annual 3St. Regis did not use Timber RAM in their process of determining their annual allowable
cut. The AAC's estimated for this study will differ from Weldwood's determination.

${ }^{4}$ Personal communcation. R.W. Udell, Assistant Chief Forester, St. Regis (Alberta) Ltd. 28 March 1984.
Table 1. Coefficients for Chapman-Richards yield functions expressing volume $\left(\mathrm{m}^{3} / \mathrm{ha}\right)$ as a function of age (years). The yield functions are of the form

$$
\text { Volume(age })=b_{1}\left(1-e^{\left(b_{2} \cdot \text { age }\right)}\right) b_{3}
$$

\begin{tabular}{lccc}
\hline & \multicolumn{3}{c}{ Chapman-Richard Parameters } \\
\cline { 2 - 4 } Type Group & $\mathbf{b}_{1}$ & $\mathbf{b}_{2}$ & $\mathbf{b}_{3}$ \\
\hline Pine & $1.9497 \times 10^{2}-4.8352 \times 10^{-2}$ & $1.4898 \times 10^{1}$ \\
White spruce & $1.9333 \times 10^{2}-7.5931 \times 10^{-2}$ & $6.1109 \times 10^{1}$ \\
Black spruce & $7.4535 \times 10^{1}-1.0973 \times 10^{-1}$ & $2.2088 \times 10^{3}$ \\
Fir & $2.2719 \times 10^{2}-5.8502 \times 10^{-2}$ & $3.6802 \times 10^{1}$ \\
Hardwood & $1.9333 \times 10^{2}-7.5931 \times 10^{-2}$ & $6.1109 \times 10^{1}$ \\
Second growth & $1.9252 \times 10^{2}-6.2914 \times 10^{-2}$ & $3.1883 \times 10^{1}$
\end{tabular}

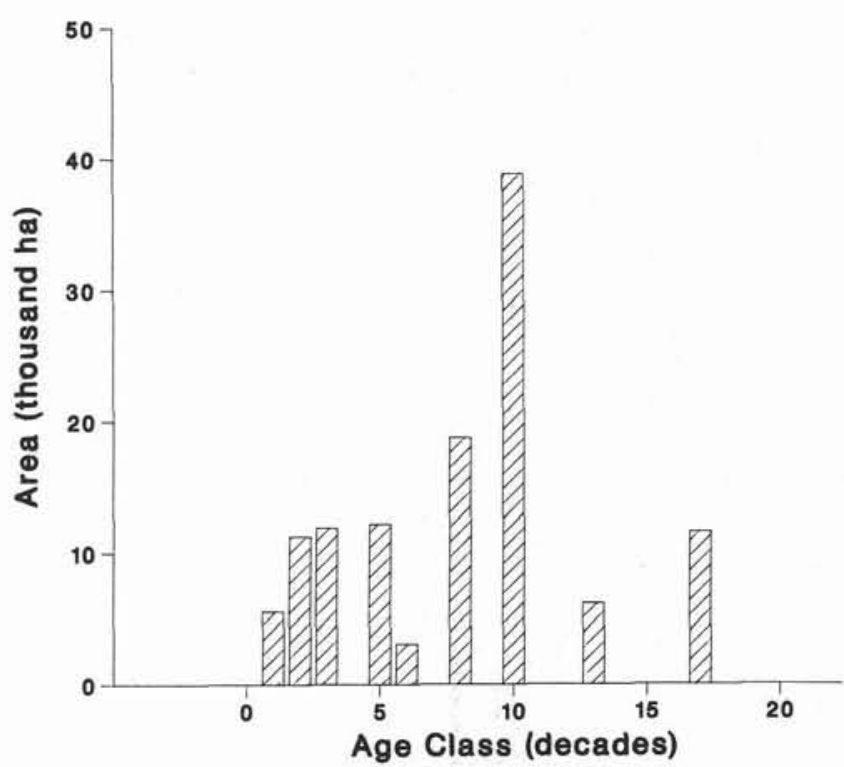

Figure 1. Forest age class distribution of the Athabasca Working Circle.

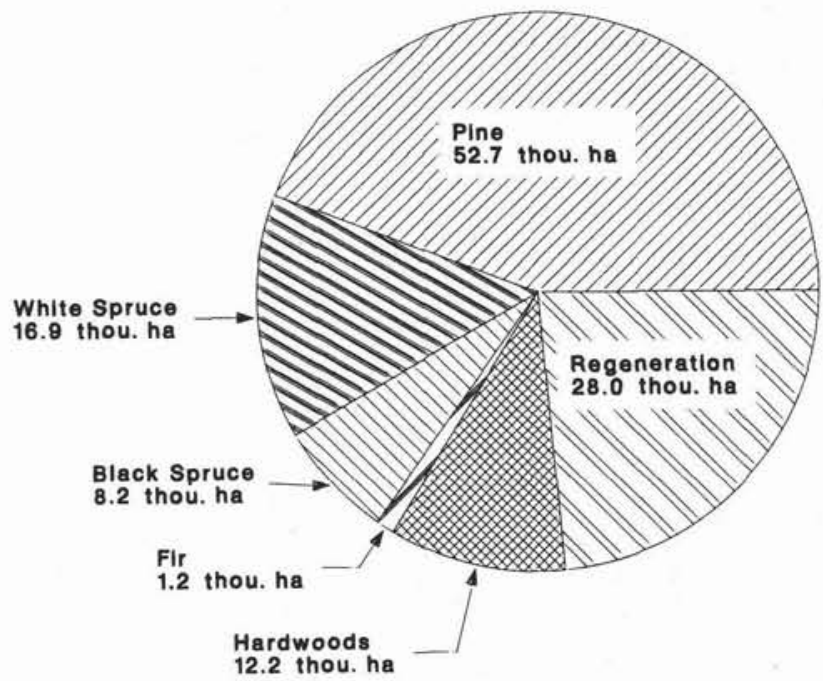

Figure 2. Area distribution by forest type group in the Athabasca Working Circle. 
allowable cut set for an FMU in Alberta is largely determined by its forest type and age class distribution. Therefore the results of this study are specific to the area under consideration, and may not be generally applicable.

Three Timber RAM runs were used for this analysis. The base run was used to represent a case in which the coal block was not developed and remained in timber production. The removal run was used to represent a scenario where the entire mine area was permanently removed from timber production. The reclamation run was used to represent a scenario where most of the land affected by the mine is reclaimed to timber production after mining is completed.

The policy of the Alberta government states that land disturbed by mining and related operations is to be returned to a state of productivity at least equal to that which prevailed prior to mining (Anon. 1976). The costs of the reclamation are to be borne by the mining company. The reclamation run is meant to model the reclamation program outlined in the coal company's impact assessment. The stated objective of the reclamation program is to return the mined area to commercial forest. Reclamation is to be a continuous process occurring as mine development proceeds.

We assume here that area 5 of the coal block (the plant site) will not be reclaimed and will be removed permanently from the land base. The clearing and subsequent reclamation of area 1 (the first 10 years of mining) is modeled by assigning all of the timber classes in this area to age class 1 , and shifting the growth curve to the right by 10 years (i.e. timber volume on the land 20 years from now will be that associated with a 10-year-old stand). The shift for area 2 is 20 years; for area 3, 30 years; and for area 4, 40 years.

This study assumes that the area to be reclaimed will be returned to the level of productivity existing before coal mining takes place. It would be trivially simple, however, to change the post-mine productivity to any appropriate level.

We estimate that with the no removal scenario, the Athabasca Working Circle is capable of producing $209809 \mathrm{~m}^{3}$ of timber per year for 160 years, and $188894 \mathrm{~m}^{3}$ of timber per year thereafter.

Under the complete removal scenario, the working circle can produce $204786 \mathrm{~m}^{3}$ per year in the first 160 years, and $184084 \mathrm{~m}^{3}$ per year thereafter. This is a reduction in productive capacity of $5023 \mathrm{~m}^{3}$ per year over the 160-year planning horizon and $4810 \mathrm{~m}^{3}$ per year thereafter.

Under the reclamation scenario, the working circle can produce $209213 \mathrm{~m}^{3}$ per year over the planning horizon and $188550 \mathrm{~m}^{3}$ per year thereafter. This represents a loss in productive capacity of $596 \mathrm{~m}^{3}$ per year in the first 160 years and $344 \mathrm{~m}^{3}$ per year thereafter.

\section{Timber Value Estimation}

The pulp company operates a bleached kraft pulp mill and a stud mill at Hinton. The values of these two commodities will be used to determine the value of timber in the Hinton area. In $1983,51 \%$ of the wood volume harvested by the company was in the form of pulpwood, the other $49 \%$ was sawlogs ${ }^{5}$. The pulpwood is assumed to be processed directly by the pulp mill and sawlogs are assumed to run through the stud mill with the residue being used in the pulping process.

${ }^{5}$ Personal communication. R.W. Udell. Assistant Chief Forester. St. Regis (Alberta) Ltd. 28 March 1984

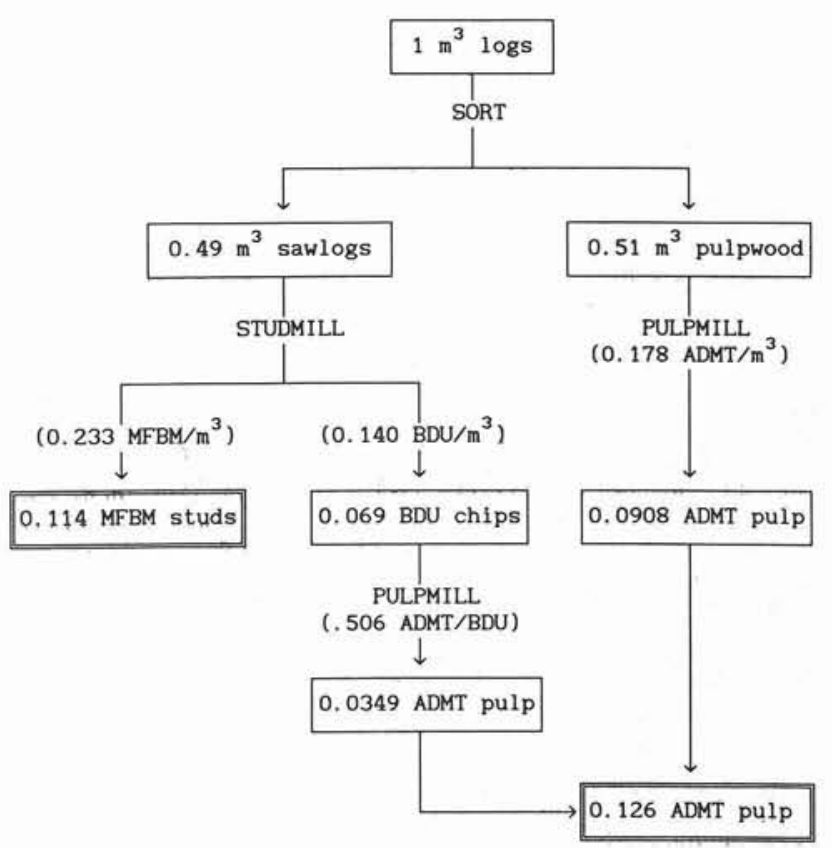

Figure 3. Schematic diagram of mill process used to calculate the stud and pulp yield of an average cubic metre of logs.

The milling process is assumed to be that illustrated in Figure 3 . The conversion factors used are based on those published by the Alberta Forest Service (Anon. 1985b). The average cubic metre of timber from the Athabasca working circle is calculated to yield 0.114 MFBM of studs and 0.126 ADMT of bleached kraft pulp.

The timber values used in this study were derived using the conversion return approach described in Phillips et al. (1988). Essentially, the value of standing timber is the selling price of the final products (f.o.b. the mill) less all the costs of producing the products (including harvesting, forest regeneration and management, log transportation, production, and mill and equipment depreciation costs). This value is an economic rent that accrues to the standing timber at harvest. All prices and costs used in this study are expressed in constant 1984 Canadian dollars.

Because costs and revenues associated with forest products manufacture fluctuate widely, low, medium, and high estimates were developed for the study to establish a range of likely timber values for the area. The estimates used here are developed from data contained in a number of sources (Bigsby 1983, K. MacDonald 1983, A. MacDonald 1983, Ekono Consultants Ltd. 1986). Table 2 presents the values used.

Pairing the low revenue with high cost estimates results in a low timber value estimate of $\$ 6 / \mathrm{m}^{3}$ of wood harvested; medium revenue and medium cost yield a medium timber value estimate of $\$ 34 / \mathrm{m}^{3}$; high revenue and low cost estimates yield a high timber value estimate of $\$ 62 / \mathrm{m}^{3}$.

\section{Opportunity Cost Estimation}

The annual loss in harvest volume multiplied by the value per cubic metre of timber represents the annual opportunity cost. Tables 3 and 4 show the calculations of this annual opportunity for the low, medium, and high timber value 
Table 2. Revenue and cost estimates, 1984 dollars.

\begin{tabular}{|c|c|c|c|c|c|c|c|}
\hline & \multicolumn{3}{|c|}{ Revenue } & \multicolumn{4}{|c|}{ Costs } \\
\hline & $\begin{array}{c}\text { Studs } \\
\text { (\$/MFBM) }\end{array}$ & $\begin{array}{c}\text { BKP } \\
\text { (\$IADMT) }\end{array}$ & $\begin{array}{l}\text { Total } \\
\left(\$ / \mathrm{m}^{3}\right) \\
\end{array}$ & $\begin{array}{c}\text { Woodlands } \\
\left(\$ / \mathrm{m}^{3}\right)\end{array}$ & $\begin{array}{c}\text { Studmill } \\
\text { (\$/MFBM) }\end{array}$ & $\begin{array}{c}\text { Pulpmill } \\
\text { (\$/ADMT) }\end{array}$ & $\begin{array}{r}\text { Total } \\
\left(\$ / \mathrm{m}^{3}\right)\end{array}$ \\
\hline Low & 180.0 & 420.0 & 73.3 & 20.0 & 80.0 & 160.0 & 49.2 \\
\hline High & 245.0 & 660.0 & 110.8 & 26.0 & 110.0 & 230.0 & 67.4 \\
\hline
\end{tabular}

${ }^{a}$ Total revenue and cost per cubic metre of timber harvested are calculated using the average yield of 0.114 MFBM of studs per cubic metre and 0.126 ADMT of BKP per cubic metre.

Table 3. Estimates of annual opportunity cost for complete removal scenario, 1984 dollars.

Time period Lost harvest Annual opportunity cost (\$)

\begin{tabular}{|c|c|c|c|c|}
\hline (years from present) & $\left(\mathrm{m}^{3} /\right.$ year $)$ & $\begin{array}{l}\text { Low } \\
\left(\$ 6 / \mathrm{m}^{3}\right)\end{array}$ & $\begin{array}{l}\text { Medium } \\
\left(\$ 34 / \mathrm{m}^{3}\right)\end{array}$ & $\begin{array}{c}\text { High } \\
\left(\$ 62 / \mathrm{m}^{3}\right)\end{array}$ \\
\hline $\begin{array}{r}1-160 \\
161-\infty\end{array}$ & $\begin{array}{l}5023 \\
4810\end{array}$ & $\begin{array}{l}30138 \\
28860\end{array}$ & $\begin{array}{l}170782 \\
163540\end{array}$ & $\begin{array}{l}311426 \\
298220\end{array}$ \\
\hline
\end{tabular}

Table 4. Estimates of annual opportunity cost for reclamation scenario, 1984 dollars.

Time Period Lost harvest Annual opportunity cost (\$)

\begin{tabular}{|c|c|c|c|c|}
\hline (years from present) & $\left(\mathrm{m}^{3} /\right.$ year) & $\begin{array}{l}\text { Low } \\
\left(\$ 6 / \mathrm{m}^{3}\right)\end{array}$ & $\begin{array}{l}\text { Medium } \\
\left(\$ 34 / \mathrm{m}^{3}\right)\end{array}$ & $\begin{array}{c}\text { High } \\
\left(\$ 62 / \mathrm{m}^{3}\right)\end{array}$ \\
\hline $1-160$ & 596 & 3576 & 20264 & 36952 \\
\hline $161-\infty$ & 394 & 2364 & 13396 & 24428 \\
\hline
\end{tabular}

estimates for the complete removal and reclamation scenarios. These opportunity cost estimates represent the cost of lost timber production opportunities to society.

To determine the total opportunity cost of the scenarios, these annual opportunity costs must be converted to present net values using the formula in equation 1 . Real discount rates of 3,5 , and $7 \%$ per annum were chosen for this analysis ${ }^{6}$. These relatively low discount rates are chosen to be consistent with the notion of social time preference as the land in question is public forest land. Tables 5 and 6 show the total opportunity cost calculated using equation 1 for the complete removal and reclamation scenarios.

Table 5. Total opportunity cost (\$) for the complete removal scenario under different timber value and discount rate assumptions, 1984 dollars.

\begin{tabular}{lrrr}
\hline & \multicolumn{3}{c}{ Annual discount rate } \\
\cline { 2 - 4 } Timber value & \multicolumn{1}{c}{$\mathbf{3} \%$} & \multicolumn{1}{c}{$\mathbf{5 \%}$} & \multicolumn{1}{c}{$\mathbf{7 \%}$} \\
\hline Low $\left(\$ 6 / \mathrm{m}^{3}\right)$ & 1004223 & 602750 & 430542 \\
Medium $\left(\$ 34 / \mathrm{m}^{3}\right)$ & 5690601 & 3415581 & 2439740 \\
High $\left(\$ 62 / \mathrm{m}^{3}\right)$ & 10376978 & 6228412 & 4448939 \\
\hline
\end{tabular}

Table 6. Total opportunity cost (\$) for the reclamation scenario under different timber value and discount rate assumptions, 1984 dollars.

\begin{tabular}{lcrr}
\hline & \multicolumn{3}{c}{ Annual discount rate } \\
\cline { 2 - 4 } Timber value & \multicolumn{1}{c}{$\mathbf{3} \%$} & \multicolumn{1}{c}{$\mathbf{5} \%$} & \multicolumn{1}{c}{$\mathbf{7 \%}$} \\
\hline Low $\left(\$ 6 / \mathrm{m}^{3}\right)$ & 118843 & 71510 & 51085 \\
Medium $\left(\$ 34 / \mathrm{m}^{3}\right)$ & 673445 & 405224 & 289484 \\
High $\left(\$ 62 / \mathrm{m}^{3}\right)$ & 1228046 & 738938 & 527882 \\
\hline
\end{tabular}

\footnotetext{
${ }^{6}$ Real discount rates are nominal discount rates with the inflation component removed.
}

The estimated cost of lost timber production opportunities under the complete removal scenario ranges from a low of $\$ 0.43$ million to a high of $\$ 10.4$ million. The median estimate is $\$ 3.4$ million. These values equate to $\$ 132, \$ 3190$ and $\$ 1050$ per hectare of land and trees in the mine area.

The estimated cost of the lost timber production opportunities under the reclamation scenario ranges from a low of $\$ 0.051$ million to a high of $\$ 1.2$ million. The median value is $\$ 0.405$ million. These values equate to $\$ 16, \$ 377$ and $\$ 125$ per hectare of land and trees in the mine area.

\section{Concluding Comments}

The model presented here provides a method of explicitly evaluating the costs of lost sustained yield timber production opportunities resulting from a change in land use. An earlier model dealing with a permanent land use change has been extended to allow for a temporary land use change such as that expected from the development of a coal mine.

Two scenarios are presented in the paper: a very pessimistic scenariio in which the entire area to be affected by a coal mine would be permanently removed from timber production, and a scenario more in keeping with government reclamation policy where most of the mined area would be eventually returned to timber production. As expected, the opportunity cost of a permanent removal is much greater than that of a temporary removal.

The relative impact of one coal mine on actual or potential timber harvest may be considered small. The energy boom of the 1970's set in motion plans for considerable coal development in the region. Had these plans fully materialized during the 1970's, significant delays in achieving timber harvest potential could have taken place. To the extent that further coal development takes place, part of the cost of development will be the opportunity cost of timber production. This opportunity cost can be minimized if harvest scheduling and coal extraction scheduling patterns are integrated. In any case, coal extraction represents, at least to a large extent, a temporary reduction in timber production potential.

\section{Acknowledgements}

This research benefited from the contributions of many people and organizations. Tim Adamson of the Obed Mountain Coal Company; Ray Ranger, Jack Wright, and Bob Udell of St. Regis (Alberta) Ltd.; and Don Fregren, Dave Morgan, and Joe Soos of the Alberta Forest Service provided us with the information needed to undertake this study. Bob Udell and Doug Walker of Weldwood of Canada Limited (Hinton Division) and an anonymous reviewer provided constructive criticism of an earlier draft of this paper. Funding was provided by the Alberta Forest Development Research Trust.

\section{References}

Anon. 1976. A Coal Development Policy for Alberta. Alberta Energy and Natural Resources. Edmonton. June 15, 1976. 38 p. 
Anon. 1979. Environmental and Socio-Economic Impact Assessment for Proposed Obed - Marsh Thermal Coal Project. Union Oil Company of Canada Limited and Rescon Coal Holdings Ltd. Hinton, Alberta. July, 1979. many pages.

Anon. 1985a. Guidelines for the Establishment of Long Term Timber Supply Levels (Annual Allowable Cuts) in Alberta. Alberta Energy and Natural Resources. Forest Service. November 18, 1985. mimeo. $13 \mathrm{p}$.

Anon. 1985b. Forest Products Conversion Factors: Background to the Various Forest Product Conversion Factors Used by the Alberta Forest Service. Alberta Energy and Natural Resources. Forest Service. Edmonton. $65 \mathrm{p}$.

Bigsby, H. 1983. Land Values for Forestry in Northern Alberta. Alberta Energy and Natural Resources. Edmonton. November, 1983. $81 \mathrm{p}$.

Ekono Consultants Ltd. 1986. Study of Chemithermomechanical Pulp
(CTMP) Production Potential for Alberta Canada-Alberta Forest Resource Development Agreement. Edmonton. 237 p + app.

MacDonald, A.P. 1983. The Utilization of Wood Chips in Alberta. Unpublished M.Sc. thesis. Dept. Rural Economy. Univ. Alberta. Edmonton. 183 p.

MacDonald, K. 1983. Potential for Agricultural Expansion Relative to Forestry in Northern Alberta. Tech. Rep. 83-06-01. Alberta Agriculture. Edmonton. $161 \mathrm{p}$.

Navon, D.I. 1971. "Timber RAM: A Long-range Planning Method for Commercial Timber Lands Under Multiple Use Management" USDA For. Serv. Pacific Southwest Forest and Range Experiment Station. Res. Pap. PSW-70. Berkeley. 22p.

Phillips, W.E., G.W. Armstrong, J.A. Beck, and K. Banskota. 1988. The opportunity cost of forest land losses to agricultural uses: An Alberta case study. For. Chron. 64: 35-39.

\section{Membership Dues 1989-1990}

\section{Active Membership}

1 st and 2 nd year after graduation (grad 1988, grad 1987)

Other new Active Members 1st year

Married or equivalent, second member only

All other Active Members

\section{Affiliate Membership}

1st and 2nd year after graduation

(grad 1988, grad 1987)

Other new Affiliate Members 1st year

Married or Equivalent, second member only

All other Affiliate Members

Members with Retired Status receiving

The Forestry Chronicle

Members with Retired Status not receiving The Forestry Chronicle

Student Members

Sustaining Members (CIF)

Sustaining Members (Other)

\section{National \\ Dues}

$\$ 73.00$

$\$ 73.00$

$\$ 73.00$

$\$ 103.00$

$\$ 73.00$

$\$ 73.00$

$\$ 97.00$

$\$ 32.00$

$\$ 00.00$

$\$ 32.00$

$\$ 33.00$

$\$ 215.00$
Section Dues

$\begin{array}{ll}\text { AL } \$ 8.00 & \text { NW } \$ 10.00 \\ \text { CC } \$ 8.00 & \text { OK } \$ 5.00 \\ \text { CH } \$ 8.00 & \text { OR } \$ 7.00 \\ \text { CO } \$ 10.00 & \text { OV } \$ 8.00 \\ \text { CR } \$ 8.00 & \text { PA } \$ 8.00 \\ \text { LW } \$ 13.00 & \text { RM } \$ 10.00 \\ \text { MB } \$ 7.00 & \text { SK } \$ 10.00 \\ \text { MR } \$ 20.00 & \text { SN } \$ 8.00 \\ \text { ND } \$ 10.00 & \text { SO } \$ 30.00 \\ \text { NO } \$ 5.00 & \text { VA } \$ 10.00 \\ \text { NS } \$ 10.00 & \text { VI } \$ 5.00\end{array}$

NS $\$ 10.00 \quad$ VI $\$ 5.00$

Upon written application, spousal members of Active or Affiliate Members, may have the dues of one of them reduced by an amount determined annually. Spousal members are members of the same Section who are living together as spouses and using the same mailing address.

The Institute year runs from July 1 to June 30 . Applications dated after January 1 will be charged half dues for that Institute year. Applications dated after April 1 will be charged no dues for that Institute year. Section dues are in addition and range from $\$ 5.00$ to $\$ 30.00$. 